\title{
Development of Immigration Policy in Japan ${ }^{1}$
}

\author{
Kyushu Sangyo University (Japan) Atsushi Kondo ${ }^{2}$
}

\section{Introduction: Immigration Flow}

My paper is divided in four sections. The first point that we should discuss is the chronological development of immigration flow in Japan. In particular, we will focus our attention on the history since World War II. Secondly, we will analyze the development of integration policy in Japan. Following that, we will consider the main issues recently discussed. Thirdly, we will examine the admission and control policy in Japan, as well as we will deal with the main issues recently caused by social changes. Lastly, we shall conclude with a criticism of a lacking a comprehensive administration office for integration policy.

In Japan, the chronological development of immigration flow can be illustrated by the six periods shown in table 1 .

Table 1. Chronological development of immigration flow 1639-

(1) No immigration during the isolation period (1639-1853).

(2) Opening the door, large emigration and colonial immigration (1853-1945).

(3) Strictly controlled immigration and emigration (1945-1951).

(4) Strict immigration even during the time of advanced economic growth (1951-1981).

(5) Strict immigration but refugees accepted and aliens' rights are improved (1981-1990)

(6) Relatively strict immigration but ethnic repatriates (front door), trainees (side door) and irregulars (back door) come to work as unskilled workers (1990- ).

\section{1) Old Comers and New Comers}

The number of registered foreigners has increased rapidly over a recent twenty-five year period as shown in table 2 .

Table 2. Number of registered foreigners by citizenship 1975-2000

$\begin{array}{rrrrrrr}\text { Year } & \text { Korean } & \text { Chinese } & \text { Brazilian } & \text { Filipino } & \text { Others } & \text { Total } \\ 1975 & 647,156 & 48,728 & 1,418 & 3,035 & 51,508 & 751,842 \\ 1980 & 664,536 & 52,896 & 1,492 & 5,547 & 58,439 & 782,910 \\ 1985 & 683,313 & 74,924 & 1,955 & 12,261 & 78,159 & 850,612 \\ 1990 & 687,940 & 150,339 & 56,429 & 49,092 & 131,517 & 1.075,317 \\ 1995 & 666,376 & 222,991 & 176,440 & 74,297 & 222,267 & 1,362,371\end{array}$

\footnotetext{
${ }^{1}$ This discussion paper was revised with new information / data added and the new version was published in Asia and Pacific Migration Journal, vol. 11, no. 4, 2002, pp. 415-436. Please cite this journal if you wish to mention this paper in your research.

${ }^{2}$ This paper prepared for presentation at the ASEM Asia- Europe Dialogue on Globalization and International Migration: Asia and European Experiences, CERI, Hotel d'York, Paris on 12-13 March 2002. Please address to all correspondence to Atsushi Kondo, KSU, Faculty of Economics, 2-3-1 Matsukadai, Fukuoka 813-8503 JAPAN, Tel/Fax 81 (0)92 673 5286; E-mail: atsushi@ip.kyusan-u.ac.jp.
} 
Koreans are the major foreign group. Many of them are descendants of immigrants during the second period of colonial immigration. They are called "old comers"3. Some new comer Koreans have immigrated to Japan while the number of old comer Koreans has decreased. That is why the number of Koreans does not vary greatly over these twenty-five years. However, the numbers of Chinese, Filipino, Brazilian and others are rapidly increasing because of Japan's economic growth since the Plaza Agreement in mid-1980, and they are called "new comers".

\section{2) Advanced Economic Growth Period with Fewer Immigrants.}

A peculiar point of Japanese immigration history is the fourth period of advanced economic growth with fewer immigrants. In Europe, on the contrary, before the economic recession of the first oil crisis in 1973 liberal immigration policy led to a huge number of economic immigrants; the so called "guest workers". What are the reasons that Japan had so little immigration at that time compared to other developed countries? A sociologist explained this observation by the following four factors:

1) large domestic migration: Japan had more farmers than Western countries and many farmers moved from rural to urban industrial areas during the period of rapid economic growth (1955-1973);

2) automation: Japan had succeeded in improving manufacturing techniques through microelectronics, robots and automation, and as a result, less demand arose for foreign unskilled workers;

3) utilization of house wives, students and elderly people as part-time labor: In Japan, university students are able to work for some hours even on week days. Usually, high school students study hard but university students do not study so hard in Japan. Additionally, labor unions are weak and managers could hire part-time (cheap) labor more flexibly than Western countries;

4) long working hours: In 1982: 2100 hours in Japan, 1690 hours in West Germany and 1650 hours in France. In the mid 1960s 2660 hours in Japan (Kajita, 1994, 18-21).

The explanation provided by a former official of the Ministry of Justice was based on the following three reasons:

1) dense population;

2) narrow land;

3) myth of a 'monoethnic' state.

It was stated that "our country is narrow, has a lot of mountains, has scarce resources, moreover, population is dense and constitutes a 'monoethnic state', therefore, there is much anxiety about admitting foreigners' settlement, and generally, people consider it is contrary to the national interest" (Kuroda, 1988, 217-8). Ideology of the ethnic nationstate was against immigration in Japan.

\footnotetext{
${ }^{3}$ There is also a small number of old comer Taiwanese (registered as Chinese).
} 


\section{II “Internationalization" Policy as Integration Policy}

Japanese governments do not use the terms "immigrants" or "immigrant policy" (integration policy). The Immigration Control Order was issued in 1951 and influenced by the USA. At first, it had a category of entrance permission as permanent residents, which is similar to US "immigrants". However, nobody ever received such an entrance permission and the Order was abolished when the new Immigration Control and Refugee Recognition Act was enforced in 1982. The term "immigration control" is often used by the national government, and the term "alien policy" used by officials (for example see Sakanaka, 2001). The reform of the Immigration Control and Refugee Recognition Act was enforced in 1990. These three reforms of immigration control regulation are connected with the development of alien policy, which includes admission, control and integration policy.

In Japan, the chronological development of alien policy after World War II can be illustrated by the three periods shown in table 3 .

Table 3. Chronological development of alien policy

(1) Exclusion, discrimination and assimilation policy (1945-1979)

(2) Equality and "internationalization" policy (1980-1989)

(3) Settlement and "symbiosis" policy (1990- )

1) Exclusion, Discrimination and Assimilation

Even old comer Koreans who lost Japanese citizenship following the end of World War II and in accordance with the Peace Treaty with Japan in 1952 are called "aliens". Their residence status was vague ${ }^{4}$ and they could not access many social rights because they lacked Japanese citizenship. If civil servants who were Koreans did not wish to lose their posts, they needed to apply for naturalization and the old assimilative naturalization procedure required them to have Japanese names. Discrimination between citizens and aliens are problematic both in public and private sectors. Therefore, there was a Koreans' movement against employment discrimination and some local governments abolished citizenship requirements for access to public housing and child allowances in the1970s.

\section{2) Equality and "Internationalization"}

The national government acknowledged that the ratification of the International Covenants on Human Rights in 1979 and the UN Refugee Convention in 1981 would require various revisions of social security laws concerning the treatment of resident aliens in Japan. Indochina refugees, or so-called boat people, are compared with the American frigates or "Black ships" in 1853 because both of them influenced the opening of Japan to foreign intercourse (Tanaka, 1995). Indeed citizenship requirements were eliminated from the National Pension Act, the Child Allowance Act and so on, but the national government's initiatives for improving aliens' rights were weak. Additionally,

\footnotetext{
${ }^{4}$ In 1965, the bilateral agreement with South Korea ensured the status of permanent resident for only citizens of South Korea and their children.
} 
the ratification of the Convention on the Elimination of All Forms of Discrimination against Women changed the Citizenship Act from the principle of patrilineal jus sanguinis to the principle of patrilineal and matrilineal jus sanguinis. This amendment had a by-product in the abolishment of the assimilative naturalization procedure to waive ethnic names. That is why Japanese governments do not use "integration policy" to refer to their policy, but rather often used "internationalization" policy or "domestic internationalization" policy in the1980s.

\section{3) Settlement and "Symbiosis"}

The national government had a will to catch up to the international standard of human rights. However, as will be noticed in the name of the Immigration Control and Refugee Recognition Act, the main idea of "alien policy" of the national government was to control resident aliens and many "internationalization" policies had to be initiated by local governments. A symbolic issue relates to the fingerprinting for alien registration cards. In contrast to the national government's directives, some local governments considered that fingerprinting was not necessary for legal residents, especially for permanent resident Koreans. Since 1993 the national government agreed to amend the Alien Registration Act to eliminate the fingerprinting obligation for permanent residents, and since 2000 for all resident aliens.

Some local governments with many resident aliens are trying for a "symbiosis" policy or multicultural symbiosis policy. The appeal for "living together (symbiosis)" is a slogan of NGOs. Since 1990, the Immigration Control and Refugee Recognition Act reform has permitted the settlement of Nikkeijin (ethnic Japanese). Since 1991, the new Special Law on Immigration Control relating to Persons and their Descendants who lost their Citizenship of Japan in accordance with the Peace Treaty with Japan has permitted old comers special permanent residence status. The largest (south) Korean organization (Mindan) requests local voting rights for permanent residents and about half (more than 1,400) of the local governments have asked for a change of the Election Act and Local Government Act. Many local governments have opened the door for access to be local civil servants even if managerial positions are still excluded. Many local governments establish their own "International Associations" to advance international exchange and to make a friendly environment for resident aliens. The International Association supports foreigners and gives information, Japanese language education, and international mutual understanding education.

4) Main Issues

\section{a) Permanent residence}

Traditional Japan's immigration policy was not willing to allow permanent residence for resident aliens. In the case of a spouse or child of Japanese or a permanent resident, a 3year residential term was required. Otherwise, a 20 -year continuous residential term was necessary to be allowed a permanent residence permit. Since 1998, this administrative practice has been deregulated. In general, a 10-year continuous residential term (but in 
cases of quasi-permanent residents and refugees, a 5-year continuous residential term, and in cases of children of Japanese, a 1-year continuous residential term) is the requirement to be a permanent resident (Koyama, 1998). Even now, the 10-year requirement for permanent residence is two times longer than the 5-year requirement for naturalization. Recently, the number of permanent residence permissions is increasing compared with naturalization permissions as shown in table 4. Especially, second generation Nikkei Brazilians and Peruvianas (children of Japanese) are rapidly becoming permanent residents.

Table 4 The Number of permanent residence permissions and naturalization permissions

\begin{tabular}{|c|c|c|c|c|c|c|c|c|c|c|c|c|c|}
\hline \multirow{2}{*}{ Year } & \multicolumn{8}{|c|}{ Permanent residence permission } & \multicolumn{5}{|c|}{ Naturalization permission } \\
\hline & Total & Chinese & Filipino & Koreans & Brazilians & Peruvian & Others & Rejects & Total & Koreans & Shinese & Others & Rejects \\
\hline 1990 & 5,663 & 1,028 & 142 & 3,666 & 32 & 5 & 790 & 260 & 6,794 & 5,216 & 1,349 & 229 & 274 \\
\hline 1991 & 5,469 & 1,236 & 227 & 2,963 & 35 & 4 & 1,004 & 240 & 7,788 & 5,665 & 1,818 & 305 & 223 \\
\hline 1992 & 4,078 & 1,325 & 313 & 1,238 & 39 & 11 & 1,152 & 474 & 9,363 & 7,244 & 1,794 & 325 & 162 \\
\hline 1993 & 3,848 & 1.067 & 387 & 1,247 & 37 & 17 & 1,098 & 412 & 10,452 & 7,697 & 2,244 & 511 & 126 \\
\hline 1994 & 6,846 & 2,123 & 1,024 & 2,025 & 111 & 29 & 1,534 & 647 & 11,146 & 8,244 & 2,478 & 424 & 146 \\
\hline 1995 & 5,932 & 1,901 & 1,112 & 1,376 & 105 & 54 & 1,384 & 366 & 14,104 & 10,327 & 3,184 & 593 & 93 \\
\hline 1996 & 9,556 & 2,958 & 1,783 & 1,935 & 359 & 474 & 2,047 & 606 & 14,495 & 9,856 & 3,976 & 621 & 97 \\
\hline 1997 & 11,583 & 3,372 & 2,088 & 1,937 & 814 & 1,133 & 2,239 & 645 & 15,061 & 9,678 & 4,729 & 654 & 90 \\
\hline 1998 & 12,934 & 3,837 & 2,495 & 2,091 & 957 & 1,304 & 2,250 & 1,529 & 14,779 & 9,561 & 4,637 & 581 & 108 \\
\hline 1999 & 19,731 & 6,514 & 3,973 & 2,782 & 1,689 & 1,497 & 3,276 & 2,662 & 16,120 & 10,059 & 5,335 & 726 & 202 \\
\hline 2000 & 30,475 & 10,593 & 5,467 & 3,454 & 3,762 & 2,323 & 4,876 & 2,471 & 15,812 & 9,842 & 5,245 & 725 & 215 \\
\hline
\end{tabular}

Source: The Ministry of Justice.

\section{b) Local Voting Rights}

Since the 1990s, there has been discussion about giving local voting rights to permanent residents. The ruling party LDP was not willing to introduce voting for aliens but after the President of South Korea came to Japan in 1998, the political climate changed. Opposition parties submitted a bill to introduce local voting suffrage for aliens and the Prime Minister expressed a positive opinion on this matter. Public opinion and the opinion of the representatives of the national parliament appear to be in favor of the denizen vote. In 2000, two governmental parties submitted a new bill on local suffrage for permanent residents except for Koreans who do not have South Korean citizenship because there is no diplomatic relations between Japan and North Korea. However, this exclusion had a serious problem of discrimination on the basis of citizenship. In 2001, two governmental parties again submitted a new bill on local suffrage for permanent residents without exceptions, but the Prime Minister Koizumi and the LDP are not willing to pass this bill because of nationalistic ideology.

\section{c) Citizenship}

It is reported that more than 330,000 individuals were naturalized in Japan from 1945 to 2000. Most of them are Koreans and Chinese as shown in table 4. The naturalization rate (the number of naturalizations per hundred foreign residents) is generally one that is relatively low compared with other OECD countries (OECD, 2001, p. 307). However, the rejected number is small due to pre-consultation being held by the District Legal Affairs 
Bureau. The amendment of the Citizenship Act in 1985 has eliminated the phrase 'Japanese name only' in the administrative guidance on naturalization. However, it is still necessary to write the name with Japanese characters (kanji, hiragana or katakana) and some characters used in Korean names are unavailable as Japanese name characters. Individuals with dual citizenship are increasing as a result of international marriages (4.5 percent of the marriages at present in Japan). In recent times, about 80 percent of Korean residents marry Japanese and almost 8,000 children are born to Korean and Japanese parents annually (Maher \& Kawanishi, 1995, p. 170). Under the 1985 revision of the Citizenship Act, children with one Japanese parent are able to have dual citizenship, but they must choose either Japanese or foreign citizenship before they reach 22 years of age. In spite of the fact that they have lived more than 50 years in Japan, many Koreans refuse naturalization. The reason is that they do not want to lose their Korean ethnic identity, which is connected with citizenship. It should be added that they do not want to forget the history of Japanese colonization, when they were forced to have Japanese citizenship and a Japanese name.

A few Korean opinion leaders have in recent years sought the possibility of retaining Korean ethnic identity while holding Japanese citizenship, namely by constructing the identity of "Korean-Japanese", but other opinion leaders continue to warn of progressive assimilation into Japanese society as a result of the growing number of Japanese citizenship holders among permanent resident Koreans (Kashiwazaki, 2000, 459). Now, in Japan, a bill for a notification system for special permanent residents (Koreans and Taiwanese from former colonies) has been prepared. This would bring wider freedom to choose ethnic name characters. However, there are many criticisms. For example, this is an alternative plan in order to oppose the bill for local suffrage for permanent residents; this notification also needs the loss of original citizenship. As for the meaning of citizenship, a famous Korean lawyer suggests that it is: 1) the symbol of independence and nation building for the first generation of Koreans; 2) the symbol of antidiscrimination for the second generation; 3) self-realization for the third generation. Additionally, mixed marriage Japanese and Japanese living abroad are appealing for the parliament to admit adult dual citizenship.

\section{d) Multicultural Education}

Lastly, discussion on multiculturalism is becoming popular and NGOs are fond of using the term "multicultural symbiosis". The former Ministry of Education started a series of surveys of the number of foreign children who are considered to be in need of Japaneselanguage instruction as shown in table 5. According to a 2001 survey, their native languages were Portuguese (39.1\%), Chinese (28.7\%), Spanish (12.5\%) and others $(19.7 \%)$. About 84.3 percent of them were receiving Japanese-language instruction, however, many of them have problems with mastering Japanese and are likely to forget their native language.

Table 5 Foreign children needing Japanese-language instruction, by type of schools.

$\begin{array}{lll}\text { Elementary Schools Junior- high schools High schools } & \text { Others } & \text { Total } \\ \text { Number of Number of Number of Number of Number of Number of Number of Number of } & \\ \text { children schools children schools children schools children schools }\end{array}$




$\begin{array}{rrrrrrrrrr}1991 & 3,978 & 1,437 & 1,485 & 536 & - & - & - & - & 5,463 \\ 1993 & 7,569 & 2,611 & 2,881 & 1,098 & - & - & - & - & 10,450 \\ 1995 & 8,192 & 2,611 & 3,350 & 1,237 & 264 & 73 & - & - & 11,806 \\ 1997 & 12,302 & 3,402 & 4,533 & 1,659 & 461 & 148 & - & - & 17,296 \\ 1999 & 12,383 & 3,162 & 5,250 & 1,665 & 901 & 224 & 51 & 41 & 18,585 \\ 2001 & 12,468 & 3,242 & 5,634 & 1,734 & 1,024 & 272 & 64 & 48 & 19,250\end{array}$

Source: Ministry of Education, Culture, Sports and Science.

Generally, Japan's governments do not consider that mother tongue education is important for foreign children. However, several local governments, especially those with many foreign children, are trying to offer mother tongue education. Many local governments have set up classes for "Education in International Understanding", which provides opportunities to touch with cross-cultural experiences and tries to develop foreign and Japanese children's international understanding.

\section{Admission and Control Policy}

Family Reunification is the main category of immigration in Japan as well as many countries in these years. Spouses or children of nationals have increased from 222,353 (in 1993 ) to 279,625 (in 2000) but spouses or children of permanent residents have slightly decreased from 7,360 (in 1993) to 6,685 (in 2000). The so-called large chain immigration has not appeared in Japan because of the strict administration of permanent residence permission.

Japan's traditional policy of not admitting foreign workers for unskilled jobs remains basically unchanged, however three detours (front door, side door and back door) have been established since the end of the 1980s.

\section{1) Re-settlement?}

There is a front door for Ethnic repatriates. This policy is connected to the idea of the ethnic nation-state. Japan was an emigration country especially in the early twentieth century. The Nikkeijin (ethnic Japanese) who are Japanese descendants with no Japanese citizenship have been estimated to be about 670000 in the United States, 530000 in Brazil, and 50000 in Peru, totaling roughly 1400000 (Kono, 1994, p. 139). The Immigration Control and Refugee Recognition Act reform in 1990 permitted the third generation Nikkeijin as well as the spouses of second and third generation Nikkeijin a quasi-permanent residence status, which has to be renewed at certain periods but which allows work without restriction. The second-generation Nikkeijin can enter and work without restriction under the residence-status of spouse or child of a Japanese national.

Although the official explanation for granting residence-work status to the Nikkeijin is to provide opportunities to visit relatives in Japan, there must also be the hidden intention of stopping further entrance of illegal workers and solving a serious labor shortage. Officially, the quasi-permanent residence status is translated into "Long-term residents" but this status can be given just after arriving in Japan and has to be renewed every 6 months, 1 year or 3 years, even if the renewal occurs with ease. Its special feature is the 
possibility to work without restriction in the same manner as permanent residents. The hidden idea of the Ministry of Justice might be included in the name "Long- term residents"; they are expected to resettle in Japan. In these 10 years, it remains unclear whether they will settle in Japan because many of them come to work to Japan and return to Brazil repeatedly.

Table 6 shows the number of Brazilian and Peruvian residents registered in Japan under foreigner registration.

Table 6 Brazilian and Peruvian residents in Japan (1986-2000)

\begin{tabular}{|c|c|c|c|c|c|c|c|c|c|c|c|c|c|c|c|}
\hline & 1986 & $\begin{array}{l}1987 \\
\end{array}$ & 1988 & 1989 & 1990 & 1991 & 1992 & 1993 & 1994 & 1995 & 1996 & 1997 & 1998 & 1999 & 2000 \\
\hline Brazilian & 2,135 & 2,250 & 4,159 & 14,528 & 56,429 & 119,333 & 147,803 & 154,650 & 159,619 & 176,440 & 201,795 & 233,254 & 222,217 & 224,299 & 254,394 \\
\hline$\%$ & 0.2 & 0.3 & 0.4 & 1.5 & 5.2 & 9.8 & 11.5 & 11.7 & 11.8 & 13 & 14.3 & 15.7 & 14.7 & 14.4 & 15.1 \\
\hline ruvian & 553 & 615 & 864 & 4,121 & 10,279 & 26,281 & 31,051 & 33,169 & 35,382 & 36,269 & 37,099 & 40,394 & 41,317 & 42,773 & 46,171 \\
\hline$\%$ & 0.1 & 0.1 & 0.1 & 0.4 & 0.9 & 2.1 & 2.4 & 2.5 & 2.6 & 2.7 & 2.6 & 2.7 & 2.7 & 2.7 & 2. \\
\hline
\end{tabular}

Source: Japan Immigration Association.

Other economic immigrants can be categorized into one of fifteen residence-statuses as shown in table 7.

Table 7 Foreign workers in Japan by status of residence, 1996-2000

\begin{tabular}{lrrrrr}
\hline Status of residence & 1996 & 1997 & 1998 & 1999 & 2000 \\
\hline Entertainer & 20,103 & 22,185 & 28,871 & 32,297 & 53,847 \\
Specialist in humanities or international service & 27,377 & 29,941 & 31,285 & 31,766 & 34,739 \\
Engineer & 11,052 & 12,874 & 15,242 & 15,668 & 16,531 \\
Skilled labor & 8,767 & 9,608 & 10,048 & 10,459 & 11,349 \\
Intra-company transferee & 5,941 & 6,372 & 6,599 & 7,377 & 8,657 \\
Instructor & 7,514 & 7,769 & 7,941 & 8,079 & 8,375 \\
Professor & 4,573 & 5,086 & 5,374 & 5,879 & 6,744 \\
Investor and business manager & 5,014 & 5,055 & 5,112 & 5,440 & 5,694 \\
Religious activities & 5,010 & 5,061 & 4,910 & 4,962 & 4,976 \\
Researcher & 2,019 & 2,462 & 2,762 & 2,896 & 2,934 \\
Artist & 272 & 276 & 309 & 351 & 363 \\
Journalist & 454 & 420 & 373 & 361 & 349 \\
Legal and accounting service & 65 & 58 & 59 & 77 & 95 \\
Medical service & 140 & 131 & 111 & 114 & 95
\end{tabular}

Source: The Ministry of Justice.

Entertainers mainly from the Philippines are the largest working residence-status group. The second largest group is Specialists in humanities or international service, which mainly comprises foreigners who have graduated from Japanese universities. However, in reality, the second largest group is trainees.

2) Trainees or Guest Workers? 
There is a side door for trainees and technical interns. As trainees (1 year) and as technical interns ( 2 years), foreigners can stay for a maximum of three years. Trainees should not accept wages but technical interns are able to earn wages. It is pointed out that the idea of the trainee and technical intern system is the transfer of technology to developing countries, but the reality of many cases is a kind of rotation system for inviting cheap unskilled foreign workers. Some scandals have been reported. For example, managers keep trainees' passports preventing their escape because they can look for better-paid work if they run away and move to other factories as 'illegal' workers. Also, the problem of intermediary exploitation (skimming of wages) has been pointed out (Komai, 2001; NIRA, 2001).

Table 8 shows the number of trainees by citizenship. Also, the numbers that have shifted from trainees to technical interns has increased from 160 (in 1993) to 13,066 (in 1998).

Table 8 Trainees in Japan by citizenship, 1996-2000

\begin{tabular}{lrrrrrr}
\hline Citizenship & 1996 & 1997 & 1998 & 1999 & 2000 & $\%$ \\
\hline Chinese & 11,449 & 14,372 & 15,646 & 16,101 & 22,163 & 61.2 \\
Indonesian & 2,783 & 4,064 & 3,709 & 3,636 & 4,506 & 12.4 \\
Filipino & 1,981 & 2,115 & 2,122 & 2,037 & 2,734 & 7.6 \\
Vietnamese & 643 & 1,369 & 1,548 & 1,619 & 2,280 & 6.3 \\
Thai & 1,170 & 1,429 & 1,865 & 1,221 & 1,802 & 5.0 \\
Others & 2,857 & 2,457 & 2,218 & 2,016 & 2,714 & 7.5 \\
Total & 20,883 & 25,806 & 27,108 & 26,630 & 36,199 & 100.0
\end{tabular}

Source: The Ministry of Justice.

In 2000, the Ministry of Justice published the Second Basic Plan for Immigration Control. The plan provides new guidelines for immigration control and acceptance of foreign workers into Japan. Under the plan, job categories in the Technical Internship Program, which have gradually been widened over time, will be reconsidered to respond more adequately to requests for more advanced skills from foreign trainees and organizations in charge of accepting trainees. Also, now that the program is already well established, thought will be given to further legislation that might bolster the system, including the creation of an independent residence-status. The Technical Internship Program is a scheme that allows foreigners to acquire further technical knowledge and skills by working at a Japanese firm on an employment contract if they satisfy certain conditions and achieve set levels in their training after spending a certain period of time in training.

Revisions will also be considered concerning foreign workers with higher technical knowledge and skills in respect of the criteria (such as years of work experience required, eligible job categories) that have to be met in order to work in Japan. As a result, new residential statuses will be considered for workers in new types of businesses where there is a high demand for skills that were not forecasted.

3) Irregulars 
There is a back door for Irregulars. According to the Ministry of Justice, the estimation of overstay persons in Japan was about 230,000 on January 1, 2001, which is a decrease in numbers compared with approximately 300,000 persons in 1993 . However, it is difficult to estimate the number of irregular residents because there is no official estimation of the number of irregular entrants. As shown in table 9, most irregular residents enter Japan legally as tourists, and then work illegally and overstay.

Table 9 Number of Irregular Residents by Citizenship and Residence-status 2001

\begin{tabular}{lrrrrrrr}
\hline Citizenship & $\begin{array}{r}\text { Temporary } \\
\text { visitors }\end{array}$ & $\begin{array}{l}\text { Enter- } \\
\text { tainers }\end{array}$ & $\begin{array}{r}\text { Pre-college } \\
\text { students }\end{array}$ & $\begin{array}{c}\text { College Trainees } \\
\text { students }\end{array}$ & Others & Total \\
\hline South Koreans & 50,881 & 44 & 666 & 605 & 42 & 3,785 & 56,023 \\
\hline Filipino & 16,413 & 9,972 & 413 & 53 & 483 & 4,332 & 31,666 \\
\hline Chinese & 7,367 & 192 & 7,980 & 3,279 & 1,080 & 11,077 & 30,975 \\
Thai & 18,252 & 37 & 144 & 40 & 293 & 734 & 19,500 \\
& & & & & & & \\
Total & 173,051 & 11,029 & 10,025 & 4,401 & 3,004 & 30,611 & 232,121 \\
Source & The & & & & & &
\end{tabular}

Source: The Ministry of Justice.

More than 95 percent of those deported left Japan at their own cost (Hômushô Nyûkoku Kanrikyoku, 1998, p. 148). Table 10 indicates the number of deported Illegal Workers by Citizenship.

Table 10 Number of deported Illegal Workers by Citizenship 1996-2000

\begin{tabular}{lrrrrrr}
\hline Citizenship & 1996 & 1997 & 1998 & 1999 & 2000 & $\%$ \\
\hline South Korea & 11,444 & 10,346 & 9,360 & 13,164 & 11,336 & 25.7 \\
\hline China (Mainland) & 7,403 & 7,810 & 7,224 & 8,278 & 8,132 & 18.4 \\
\hline \multicolumn{1}{c}{$\quad$ (Taiwan) } & 437 & 557 & 429 & 466 & 492 & 1.1 \\
\hline \multicolumn{1}{c}{ (Hong Kong etc.) } & 82 & 112 & 53 & 60 & 36 & 0.1 \\
The Philippines & 5,646 & 5,067 & 5,631 & 6.672 & 7,420 & 16.8 \\
Thailand & 5,561 & 4,483 & 3,604 & 3,926 & 3,902 & 8.8 \\
Iran & 3,180 & 2,225 & 2,219 & 1,639 & 1,598 & 3.6 \\
Peru & 4,034 & 1,694 & 1,746 & 1,459 & 1,458 & 3.3 \\
Malaysia & 2,214 & 1,579 & 1,350 & 1,429 & 1,288 & 2.9 \\
Pakistan & 1,418 & 1,152 & 1,255 & 1,314 & 1,217 & 2.8 \\
Indonesia & 817 & 957 & 1,210 & 1,220 & 1,090 & 2.4 \\
Bangladesh & 926 & 930 & 1,067 & 1,082 & 1,073 & 2.4 \\
Others & 4,623 & 4,692 & 5,387 & 5,549 & 5,148 & 11.5 \\
Total & 47,785 & 41,604 & 40,535 & 46,258 & 44,190 & 100.0
\end{tabular}

Source: The Ministry of Justice.

Japan has no experience of general amnesty, however there are some precedents of special permission for residence on humanitarian grounds being granted to hundreds of Koreans who entered Japan "illegally" in recognition that they had established their home base in Japan. Some of these returned to Korea after the World War II but could not re- 
establish their lives in Korea and re-entered Japan as stowaways. Also, the Minister of Justice regularized foreign spouses of citizens or permanent residents.

Recently, in 2000 the Minister of Justice decided to allow regularization for long-term irregular resident families with school children. Twenty persons of five families granted special residence permission as quasi-permanent residence, but sixteen persons of five families and two singles were rejected. Public reaction in Japan is not so negative for special residence permission, however it is negative for general amnesty because of the fear of accelerated flows of new illegal migrants. Some politicians are appealing to the public about crime by illegal entrants. In February 2001 the Cabinet Office released the findings of its Opinion Survey Concerning Foreign Workers in Japan. Where work by undocumented workers was concerned, 49.2 percent believed that illegal work was not desirable. However, 40.4 percent felt that it was not desirable but also that it could not be helped. When asked about the amnesty for irregular residents under a certain condition such as long-term stable residence, 17.0 percent supported amnesty; 22.1 percent objected to amnesty; 49.2 percent replied that they could not generally say yes or no; 11.7 percent replied that they did not understand (Cabinet Office, 2001).

4) Main issues

a) Refugees

The Japanese government ratified the Convention Relating to the Status of Refugees in 1981 and the related protocol in 1982. Japan does not have a quota system. Refugee recognition shall be made according to the Convention Relating to the Status of Refugees, based upon the definition of a refugee described in the Convention. There were 2,532 applications as of the end of 2001 from the start of the Refugee Recognition system, of which 291 were recognized and 1,721 were not recognized. Table 11 shows the numbers of recognized refugees and not recognized persons.

Table 11 Number of Recognized Refugees and Not Recognized Persons

\begin{tabular}{|l|r|r|r|r|r|r|r|r|r|r|r|r|r|r|r|r|r|r|r|r|}
\hline \multicolumn{1}{|c|}{ Year } & 1982 & 1983 & 1984 & 1985 & 1986 & 1987 & 1988 & 1989 & 1990 & 1991 & 1992 & 1993 & 1994 & 1995 & 1996 & 1997 & 1998 & 1999 & 2000 & 2001 \\
\hline Recognized & 67 & 63 & 31 & 10 & 3 & 6 & 12 & 2 & 2 & 1 & 3 & 6 & 1 & 2 & 1 & 1 & 16 & 16 & 22 & 24 \\
\hline Not Recognized & 40 & 177 & 114 & 28 & 5 & 35 & 62 & 23 & 31 & 13 & 40 & 33 & 41 & 32 & 43 & 80 & 293 & 177 & 138 & 316 \\
\hline
\end{tabular}

Source: The Ministry of Justice.

In the case where a foreigner has special circumstances such as a difficulty in going home due to the situation in his or her home country even if a person is not recognized as refugee, the person is granted special residence permission to stay even after the application of refugee is rejected. As of the end of 1998, a total of 156 foreigners were granted permission to stay in Japan in such circumstances

UNHCR (2000) explained Japan's situation precisely. “Of the major industrialized countries, Japan, which has been a party to the 1951 UN Refugee Convention since 1981, has received by far the smallest number of asylum applications. The country's ethnic and cultural homogeneity has been sustained by strict controls on population movement and immigration, although over 10,000 Indochinese refugees have been resettled or allowed 
to remain in Japan since 1975 . In the 10 years from 1990 to 1999 , only 1,100 people applied for asylum in Japan. A strict time limit for making an application for asylum and an unusually high standard of proof meant that between 1990 and 1997, fewer than four per cent of these were recognized as refugees under the Convention. In 1998 and 1999, more asylum determinations were made than in the preceding decade, and the acceptance rate rose to over seven per cent in 1999, while an increasing number of rejected asylum seekers were allowed to remain on humanitarian grounds. Outside its borders, the Japanese government's commitment to refugees is reflected in its strong support for UNHCR's programmes".

In the Japanese Parliamentary discussion in October 2001, the small number of recognized refugees was pointed out in comparison with other countries. In the 10 years from 1990 to 1999, the approximate number of Convention refugees was 156,700 in Germany, 73,100 in France, 82,300 in the USA, but only 49 in Japan.

\section{b) Semi-skilled labor}

In 1992, the Ministry of Justice published its First Basic Plan, which lays down guidelines and administrative measures concerning the control of entry and residence of foreigners in Japan. It incorporated a vision for the coming five years based on its assessment of how internationalization is occurring. It recommended an approach to immigration control suitable for "a new era." It was the first time that such a plan referred to the mutually beneficial existence of Japanese and foreigners as a goal for Japan's immigration policy. In 2000, the Ministry published the Second Basic Plan. The general course proposed by the plan is that foreigners who contribute to globalization and respond to the needs of Japanese society be accepted more smoothly into Japan in keeping with trends towards globalization and in response to social needs. It will enlarge the various acceptable types of work by technical interns. Up to now, fifty-five types of work, such as in the machine, textile and construction industries, have been allowed for technical interns. The plan mentions widening the types of work to include agriculture, the marine products processing industry and hotel management as well as making a new independent status of residence for technical interns (The Ministry of Justice, 2000).

Under the First and Second Basic Plans, the conditions for landing permission of foreigners with the intention of working were to be reviewed according to the needs and changes of the Japanese society. Acceptance of the so-called "simple labor" was to be carefully examined, and on the contrary, specialized and technical labor was to be positively accepted. "Simple labor" is a magic word of Japan's immigration policy. What is simple labor? The image of this term is unskilled workers in contrast with skilled workers. However, its reality is determined by residence-status in the Immigration Control and Refugee Recognition Act. All foreigners who cannot be permitted residencestatus are regarded as simple labor even if they have high or medium skills. On the contrary, trainees, technical interns, the Nikkeijin, spouses of Japanese citizens and so on are not regarded as simple labor even if they work as unskilled labor. Under these circumstances, there is an opinion that the promotion and further enrichment of the trainee system and technical internship program will bring a flow of semi-skilled labor 
from within Asian countries (Iguchi, 2001). However, I do not believe that the trainee system and technical internship program will be used as a method of transferring technology as previously shown in large-size enterprises. Such large-size enterprises will increasingly transfer factories from Japan to foreign countries. On the contrary, small and medium-size enterprises are more and more demanding trainees and technical interns as cheap labor in the so-called $3 K(3 \mathrm{D})$ jobs, namely kitsui (demanding), kitanai (dirty) and kikenna (dangerous). In my view, the technical internship program should be abolished and the trainee system should be strictly checked for conditions of training.

\section{c) IT engineers}

The Second Plan did not specifically mention IT engineers, but did mention the "promotion of international cooperation through the exchange of engineers in the Asia Pacific region. In concrete, in order to execute more positive acceptance of engineers and skilled workers, the conditions regarding the requested status of residence such as the number of years of experience and the kinds of occupations shall be reviewed. In cases when a specific need is recognized and it is deemed appropriate to grant the acceptance of work not qualified under the present status of residence, rearrangements of status of residence shall be studied so that foreign engineers and skilled workers shall not adversely affect the labor market or social life of Japanese nationals and that such foreigners may act with more mobility".

\section{d) Aging Society}

The Ministry of Foreign Affairs in Japan reported in November 1999. "We should recognize 'nursing care provider' as a visa category, substantially expand our recognition of certifications granted by the governments of other countries, and relax visa requirements and immigration screening criteria. Visa requirements and immigration criteria should be relaxed for nurses as well" (The Ministry of Foreign Affairs, 1999). The Ministry of Justice mentioned guidelines in the Second Plan. Since a labor shortage is feared as a result of future population decrease with a medium to a long term perspective, some have expressed opinions that acceptance of foreign workers should be studied now in the fields, such as nursing of aged people, where needs shall grow in an aging society.

On 17 March 2000, the Population Division of the Department of Economic and Social Affairs (DESA) released a new report titled "Replacement Migration: Is it a Solution to Declining and Aging Populations?" Replacement migration refers to the international migration that a country would need to prevent population decline and population aging resulting from low fertility and mortality rates. It is reported that "in order to keep the seize of working age population at the 1995 level or 87.2 million, Japan would need 33.5 million immigrants from 1995 through 2050. This means an average of 609,000 immigrants needed per year during this period" (Population Division of the UN, 2001). Table 12 shows the prospect of total population and proportional aged 65 years and older in several countries. 
Table 12 Prospect of total population change, and proportional aged 65 years and older between 2000 and 2050 on the condition of zero immigration

(Thousands and percentages)

$\begin{array}{lcc}\text { Country } & \text { Population change } & \text { Proportional aged } 65 \text { years or older } \\ \text { Japan } & -21793 & 17 \%-32 \% \\ \text { Italy } & -16101 & 18 \%-35 \% \\ \text { Germany } & -8917 & 16 \%-28 \% \\ \text { UK } & -2163 & 16 \%-25 \% \\ \text { France } & 803 & 16 \%-26 \% \\ \text { USA } & 70951 & 13 \%-22 \%\end{array}$

See Population Division of the UN (2001).

From the Population Division of the UN (2001) research, we can estimate that Japan needs the largest amount of immigrants in the future. Even in an economic recession period, it is often pointed out that the demand for future immigrants in Japan exists. However, the future is not clear for the industrial structure and pension system and so on. It is difficult to forecast the future industrial structure and social security system because they are extremely different over the last 50 years. Even if the IT industry is now in a recession period, immigration of IT engineers is also widely discussed in many industrial countries. The German Green Card and discussion on introducing a Point System are interesting in Japan and other European countries.

The Opinion Survey (Cabinet Office, 2001) asked questions about prospects for the future. In connection with the shrinking population, 26.4 percent felt that "the shortage in the labor force will be a serious problem everywhere;" 41.6 percent, that "the shortage in the labor force will be a serious problem in some job categories;" and 31.6 percent, that "the shortage in the labor force will not necessarily be a serious problem." In line with these views, 33.8 percent felt that the government should "aggressively enforce whatever policies for foreign nationals it had in place," while 37.9 percent felt that the government should be "moderately serious in enforcing such policies".

\section{Concluding Remarks: Lack of Comprehensive Administration}

The Second Basic Plan pointed out that the "construction of comprehensive administration, not fragmentary parts of individual administrative fields, for foreigners is required in the future". The Ministry of Justice is dealing with immigration control but there is no governmental office in charge of integration policy. The Ministry of Home Affairs was dismantled and several ministries were established after World War II. Integration policy is especially related to the Ministry of Health, Labor and Welfare, the Ministry of Economy, Trade and Industry, the Ministry of Education, Culture, Sports and Science, the Ministry of Justice, and the Ministry of Land, Infrastructure and Transportation. The former Ministry of Labor thought of introducing a work permission system such as in European states, however, the Ministry of Justice rejected it in 1988.

Finally, it seems appropriate to remark that if we consider the future globalization of aging society in Japan, we need to discuss the reform of the admission system from the 
"positive list" to the "labor market test" such as in European states or "point system" such as in Canada. The so-called "sectionalism" in the government will be solved and a new comprehensive administration office for integration policy will be established directly under the Cabinet Office (Yamawaki et al., 2001).

\section{References}

Cabinet Office. (2001). Gaikokujin rôdôsha mondai ni kansuru seron chousa (Opinion Polls Concerning Foreign Workers in Japan).

In http://www8.cao.go.jp/survey/h12/gaikoku/2-2.html.

Hammar, T. (1990). Democracy and the Nation State: Aliens, Denizens and Citizens in a World of International Migration. Aldershot: Avebury.

Hômushô Nyûkoku Kanrikyoku (The Immigration Bureau in the Ministry of Justice). (Ed.). (1998). Heisei 10 Nenban Shuutsunyûkoku Kanri (Immigration Control, 1998 ed.) .Tokyo: Ôkurashô Insatsukyoku,

Iguchi, Y. (2001) Gaikokujin rôdosha shin jidai (New Age of Foreign Labor). Tokyo: Chiukuma Shobo.

Kajita, T. (1994). Gaikokujin rôdôsha to Nihon (Foreign workers and Japan). Tokyo: Nihon Hôsô Kyôkai.

Kashiwazaki, C. (2000). Citizenship in Japan: Legal Practice and Contemporary Development. In T. A. Aleinikoff \& D. Klusmeyer (Ed.), From Migrants to Citizens. Washington, D. C.: Carnegie Endowment for International Peace. (pp. 434-471).

Komai, H. (2001). Foreign Migrants in Contemporary Japan. Melbourne: Trans Pacific Press.

Kondo, A. (2001). Comparative Citizenship and Alien's Rights. In A. Kondo (Ed.), Citizenship in a Global World: Comparing Citizenship Rights for Aliens. (pp. 225-248) London: Palgrave.

Kono, S. (1994). International Migration in Japan: A Demographic Sketch. In W. Gooneratne et. al. (Eds.), Regional Development Impact of labor Migration in Asia. (pp. 137-150). Nagaya: United Nations Centre for Regional Development.

Koyama, N. (1998). Zairyû Shikaku "Eijûsha" ni tsuite (On the Status of Permanent Residents) Kokusai Jinryû (The Immigration Newsmagazine) no. 138. (pp. 25-27).

Kuroda, T. (1988). Gaiji hô (Foreign Affairs Law). Tokyo: Gyôsei. 
Maher, C. \& Kawanishi, Y. (1995). 'Maintaining Culture and Language: Koreans in Osaka', in J. C. Maher and G. Macdonald (eds.), Diversity in Japanese Culture and language. (pp. 160-177). London: Kegan Paul International.

NIRA/ Citizenship research group (Ed.), (2001). Tabunka shakai no sentaku; citizenship no shiten kara (Choice of Multicultural Society: From the perspective of citizenship).

Tokyo: Nihon Keizai Hyôron Sha. (Chapters of trainees and interns are written by Chieko Kanbayashi and Akira Hatade).

OECD. (2001). Trends in International Migration. SOPEMI 2000 ed. Paris: OECD

Population Division of the UN (2001). Replacement Migration: Is It a Solution to Declining and Ageing Populations? New York: United Nation.

Sakanaka, H. (2001). Nihon no gaikokujin seisaku (Alien Policy in Japan). Tokyo: Nihon Kajo Shuppan.

Tanaka, H. (1995). Zainichi Gaikokujin (Alien Residents in Japan). New Version. Tokyo: Iwanami Shoten.

The Ministry of Foreign Affairs. (1999). Report of the Mission for Revitalization of Asian Economy -Living in Harmony with Asia in the Twenty-first Century -.

In http://www.mofa.go.jp/policy/economy/asia/mission99/report/index.html.

The Ministry of Justice. (2000). Basic Plan for Immigration Control. The 2nd edition. In http://www.moj.go.jp/ENGLISH/IB/IB2000/ib.html.

UNHCR (2000), The State of the World's Refugees 2000. Geneva: Oxford University Press.

Yamawaki, K., Kondo, A. \& Kashiwazaki, C. (2001). Taminzoku kokka Nihon no Kôsô (Vision for Japan as a multiethnic country). Sekai July 2001.. 